\title{
Technical and Economic Aspects to Increase the Income of Seaweed Farmers in Milangodaa Village, Popayato Timur Subdistrict, Gorontalo
}

\author{
Anes Dwi Jayanti ${ }^{1, *}$, Suadi ${ }^{1}$, Sitty Ainsyah Habibie ${ }^{2}$, Ana Ariasari ${ }^{3}$ \\ ${ }^{1}$ Fisheries Department, Faculty of Agriculture, Universitas Gadjah Mada, Indonesia \\ ${ }^{2}$ Faculty of Fisheries and Marine Sciences, Gorontalo State University, Indonesia \\ ${ }^{3}$ Faculty of Geography, Universitas Gadjah Mada, Indonesia
}

\begin{abstract}
Milangodaa Village, Popayato Timur Subdistrict is one of the important seaweed cultivation locations in the Gorontalo province. But in recent years there has been a decline in both the productivity and quality of seaweed produced from this region. This research was conducted to determine the factors that caused a decrease in productivity and strategies to increase the productivity and income of seaweed farmers in the area. This research was conducted with a triangulation method that combines area of study, interviews, and using secondary data. Factors that make a decrease in productivity are diseases, scarcity of seed availability, the fell of seaweed price, and the decreased trust among farmers to the role of institutions and groups in tackling problems. The farmers' income can be increased by applying the harvest strategy, applying the technical approach such as increasing the area of cultivation, improving the distribution system of seeds and crops, and improving facilities and infrastructure such as anchoring ports and boat capacity. The economical approach consisted of financial sheet assistance, increase the bond among farmers through engaging community and institution as well as agreement on the management of input supply, access and marketing, and distributing the output.
\end{abstract}

\section{Introduction}

Seaweed farming is an important source of income for major coastal households in Southeast Asia [1]. It is a major aquaculture sector and also it has been cultivated worldwide. China, Indonesia, Japan, and Rep. of Korea are listed as the biggest seaweed producer [2]. The widespreading causal of simplicity, cheap investment and genderless activities where children and women can access this business activity [2]. Besides its economic impact, seaweed aquaculture also provides environmental service which is the removal of nitrogen pollutant came from land runoff and enters the sea [3]. Among the cultivated species of seaweed, Kappaphycus and Eucheuma are the vast majority of species farmed in Indonesia, reaching over 9.0 million tons and dominated $83 \%$ global production [3].

Indonesia plays a significant role in the world's seaweed business and often is a direct market for seaweed from Malaysia [4]. In a decade, Indonesia seaweed export increase from

\footnotetext{
*Corresponding author: anes.dwijayanti@ugm.ac.id
} 
more or less 120 million USD to 240 million USD in 2014. However, there is a gradual decrease after its peak in 2014 and the last recorded trade value was 170 million USD in 2016 [8]. It also reflects a decrease in production in many places in Indonesia. One example is in Milangodaa Village, Popayato Timur Subdistrict. Popayato Timur used to be the most productive seaweed farming area in Gorontalo, until 2016 when the production plunged 15 times lower. However, both local and state government optimist that adding some facilities will revitalize seaweed business in the community.

Some reinforcement and assistance have been delivered to overcome the low productivity of seaweed farms. However, most of the aid failed to solve the problem. A lot of factors can be the cause of the failure and every region has specific factors. Therefore, specific handling is needed to be done in each area to overcome the problem effectively. This paper will discuss the urgency to recognize the technical and economical aspect that is typical in Popayato Timur and generate a solution to increase the productivity of seaweed.

\section{Materials and Methods}

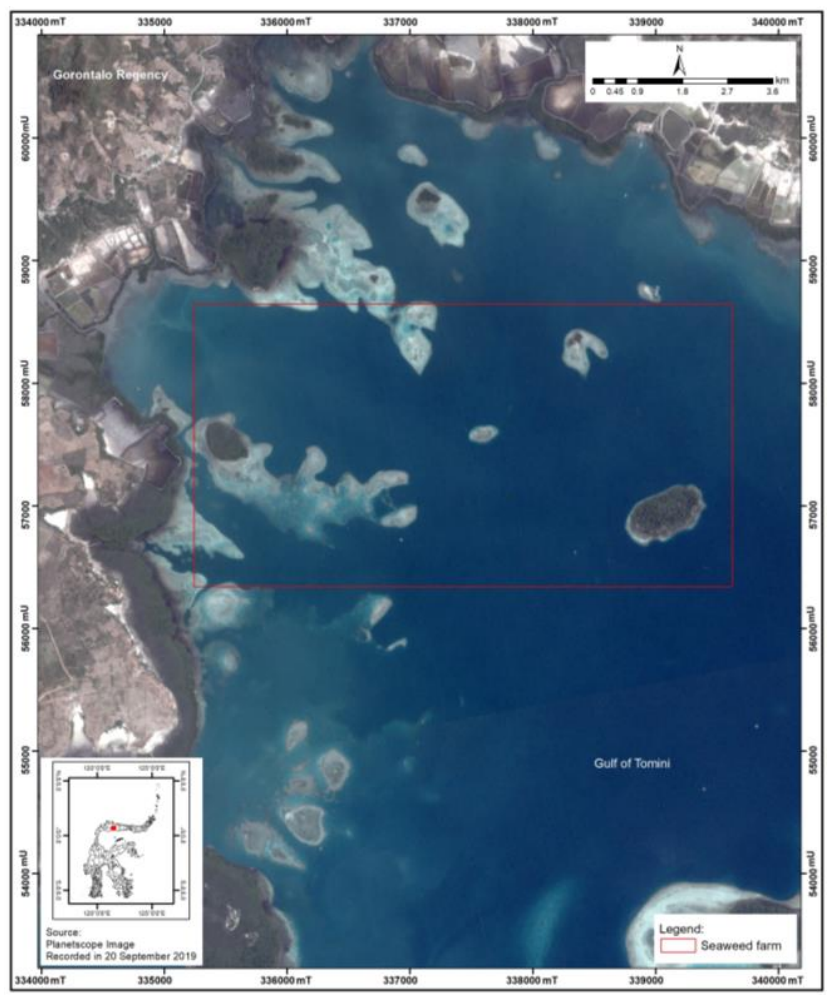

Fig. 1. Research Site, MilangodaaVillage, Popayato Timur Subdistrict, Pohuwato Regency, Gorontalo.

The Research was done in Milangodaa Village, Popayato Timur Subdistrict, Pohuwato Regency, Province of Gorontalo, Indonesia. Milangodaa village was chosen as a research site because it is the only village that continues its cultivation business in the subdistrict. Fig. 1 illustrates the research site. This research was conducted with a triangulation method [5, 6], which included three sections. The first was area study or site observation, the second was interviews, and analyzing available data from the government. Area study was performed which focused on access to the seaweed farm, the availability of communal, and 
individual facilities both on-farm and post-harvest. Depth interview was performed to gain information regarding seaweed farming history and its important timeline as community livelihood. The third was analyzing the quantitative data from the survey and available source from government, village and residence authority. Key informants such as coordinator of seaweed group, head of the village, seaweed technical assistance from state and residence governments, seaweed middle-man, seaweed company, and influential seaweed farmer. There were 15 respondents who are active seaweed farmers, accounted for $80 \%$ of the total active seaweed cultivator.

The framework of the research in Fig. 2, describe the connectivity of natural, cultural and structural aspects in the community that its livelihoods come from seaweed cultivation. The natural aspect stands for the environmental condition such as the micro and macro climate, season and water quality. The natural condition is general and widely occurred. The structural aspects represent the physical development in the village that affects directly to seaweed farming and business, such as road, canal, warehouse, drying area, boat, machine, and dock.

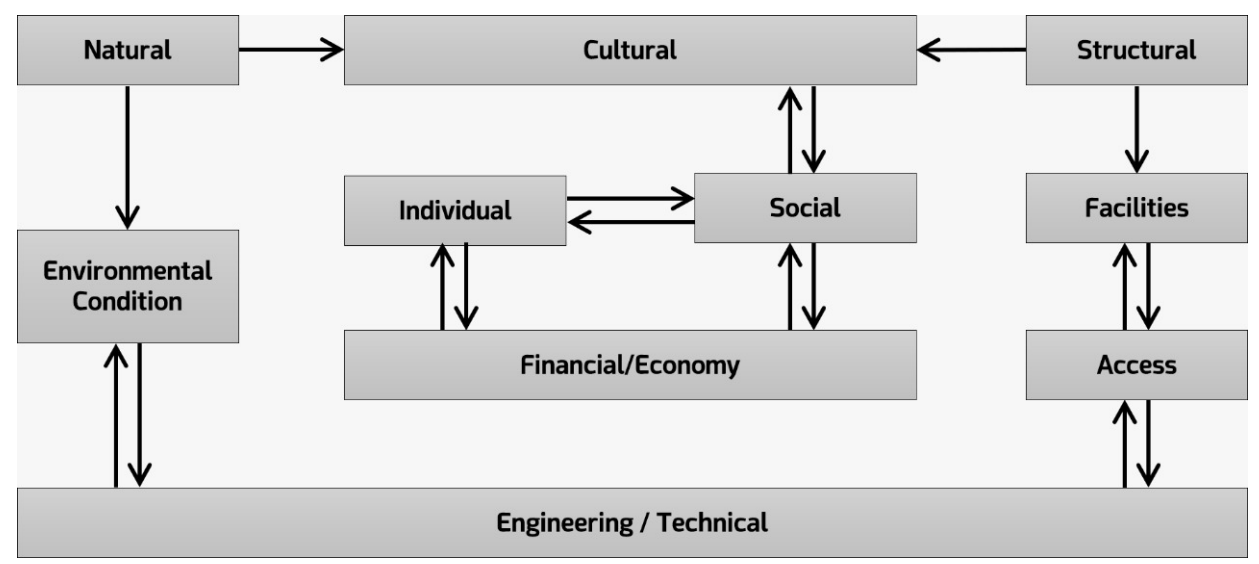

Fig. 2. Research framework.

In this framework, structural and natural aspects are also influencing the cultural aspect so that the community could consider seaweed farming as one of their livelihoods and develop it into their main income source. The cultural aspect is formed from social consensus which is derived from individual experience. In seaweed farming, social and cultural have a clear interaction on the importance degree of seaweed farming for the community. Both aspects supposed to be triggered by two important factors, engineering or technical and economy or financial. Therefore to promote the cultural aspect of seaweed cultivation can be derived from identifying and reinforce the economic and technical aspects.

\section{Results}

\subsection{The Existing Seaweed Business in Milangodaa, Popayato Timur}

Seaweed farmers were eighty people and only 12 farmers survive and continue to cultivate seaweed. Some of them have no other livelihood source. Safe environment, simple maintenance and low cost of seaweed cultivation made it is accessible for women, children, and the elderly [2]. Farmers possess 100-150 lines, which each of them is $25 \mathrm{~m}$ long. Compare to Bantaeng District, and other areas in Indonesia in general [7] the average of lines owned by the farmers are approximately 600 lines. This capital results in the difference in production. 
Table 1. The average of Milangodaa, Popayato Timur seaweed farmers capital and farming method.

\begin{tabular}{lcc}
\hline \multicolumn{1}{c}{ Criteria } & Milangodaa, Popayato Timur & $\begin{array}{c}\text { Indonesian Seaweed Farmers } \\
\text { in General }\end{array}$ \\
\hline Seaweed line possession & Seaweed Farmers & 600 lines, $(15.000 \mathrm{~m})$ \\
Seedling re-use & 100-150 lines, $(3750 \mathrm{~m})$ & More than 4 years \\
Frequent maintenance & More than 4 years & 3 times a week \\
Harvest strategy & Once a week & 8 cycles in a year, continuous \\
\hline
\end{tabular}

* Source: World Bank [4] with modification and survey

The fall of seaweed production not only due to the line possession and farmers' capital. It is interlinked with the falling price, shifting species to the cheaper value, and improper production facilities. The fall of seaweed production in Popayato started in 2016, the seaweed declines 15 times lower. The identified technical aspects are the lack of sufficient infrastructure and poor cultivating management. Improper infrastructure leads to some difficulties in seaweed initial installation, maintenance, and harvesting. Some of the aquaculture techniques done by the farmers are different from the production standard [9]. Quay or dock, and paved street which can quicken the transport of harvested seaweed or the seedling are unavailable. It caused poor maintenance of seaweed and increasing the cost. The technical and economical aspects are listed in Table 2. The technical and economical aspects are related to one another and caused the complexity in the seaweed business in Milangodaa, Popayato Timur. This similar situation could also happen in the other location remote from the market access.

\subsection{Seaweed Business Requires Quality, Quantity, and Continuity}

The prevailing factor of seaweed business downturn is the technical aspect and our finding suggests that the shifting commodity from $K$. alvarezii to the E. spinossum is the catalyst for seaweed business crash. The value of $K$. alvarezii was IDR $18.000 / \mathrm{kg}$ (2015 price, moreless $1,28 \mathrm{USD} / \mathrm{kg}$ in 2019 rate), plunged to IDR $3.000 / \mathrm{kg}$ (0.21USD) for E. spinossum in 2019 price rate. This incident made farmers unwilling to continue their livelihood as a seaweed farmer. The seaweed previous price exceeded the high cost of production due to the inadequate facilities such as road, dock, shallow river, boat, warehouse and vehicle to transport the yield. The value loss due to this shifting is IDR 750.000 (USD 53.53)/month in 2019 and it is far bigger than if it were compared to the price of K. alvarezii in 2015 (Table 3). Meanwhile, in The Philippines, the price of fresh seaweed is 0.05USD [1].

Milangodaa, Popayato Timur environmental condition only supports E. spinossum to grow optimally. There were no further studies revealing the primary environmental factors of the shifting commodity. However, the shifting land use is accused as the leading factor for this environmental change. Within five years the land use of the coastal area near the estuary and around the cultivating area has changed dramatically from mangrove area to milkfish and shrimp brackish water pond. Dealing with the actual environmental condition which suitable for E. spinossum and lacking the facilities, some suggestion that we propose for revitalizing the seaweed cultivation in Milangodaa, Popayato Timur are; 1) optimize the revenue, reducing cost; 2) increase the cultivator bargaining position.

The price of E. spinossum will not be significantly changed, therefore the technique to maximize the profit is to reduce the cost or increase the revenue. Setting the targeted income from seaweed cultivation monthly and regularly is critical. Farmers are triggered to have a wise cultivate and harvest strategy. When individual planting and harvesting plans on their plot are designed and succeed, the total production of a larger communal scale could be projected. By doing this, the quantity of seaweed can lure more buyer to purchase their harvest yield and escalate farmer bargaining positions. The abundance of yield will decrease the transportation and storage cost, remaining the bigger margin for farmers. To escalate 
more revenue, establishing collective marketing trough local market, adjust local institution agreed by most of the farmers, seaweed stakeholders, and devising local business or institution to undertake seaweed auction. With more buyers participating in the auction process, a reasonable price can be settled.

\subsection{Improving the Access and Facilities, Smoothing the Seaweed Supply Chain from Farm to the Market.}

Based on the observed situation in Table 2, there are few things that urge to be done. First of all is building the road access to the docking area, establish proper dock and quay, continued with widening the canals and river banks so that bigger boats can access the land area easily. Upscale the boat size up to 5GT for installation and harvesting, 1 GT or fewer capacity boats are still used to do weekly maintenance. Besides on the production side, the post-harvest side is important.

Table 2. The cause of declining production and the correlation.

\begin{tabular}{|c|c|c|}
\hline Aspect & Direct Effect & $\begin{array}{c}\text { Indirect Effect } \\
\text { Occurs }\end{array}$ \\
\hline \multicolumn{3}{|l|}{ Technical Aspect } \\
\hline $\begin{array}{l}1 \text { Insufficient docking } \\
\text { facilities, far distance } \\
\text { from quay to seaweed } \\
\text { farm plot }(4.5 \mathrm{~km})\end{array}$ & $\begin{array}{l}\text { Difficulties in transporting seed from } \\
\text { land to the farming plot, and } \\
\text { transferring harvest from boat to the } \\
\text { land }\end{array}$ & $\begin{array}{l}\text { High cost in fuel } \\
\text { consumption }\end{array}$ \\
\hline $\begin{array}{l}2 \text { Narrow, shallow and } \\
\text { muddy river as the only } \\
\text { access to the village ( } 817 \\
\text { m) }\end{array}$ & $\begin{array}{l}\text { Increase fuel consumption, decrease } \\
\text { seaweed quality }\end{array}$ & $\begin{array}{l}\text { High cost in } \\
\text { consumption, lower } \\
\text { price of seaweed }\end{array}$ \\
\hline $\begin{array}{l}3 \text { Small boat capacity less } \\
\text { than } 1 \text { GT }\end{array}$ & $\begin{array}{l}\text { More frequent trip land to seaweed } \\
\text { plot for seedling installation, and } \\
\text { harvesting }\end{array}$ & $\begin{array}{l}\text { High cost in fuel } \\
\text { consumption and labor }\end{array}$ \\
\hline $\begin{array}{l}4 \text { Unplanned planting } \\
\text { schedule and maintenance }\end{array}$ & $\begin{array}{l}\text { Inefficient plot and resource } \\
\text { utilization }\end{array}$ & $\begin{array}{l}\text { Low production, low } \\
\text { revenue, improvidence } \\
\text { fuel cost }\end{array}$ \\
\hline $\begin{array}{l}5 \text { Seedling availability and } \\
\text { its degenerating quality }\end{array}$ & $\begin{array}{l}\text { Vulnerable to "ice-ice" diseases, low } \\
\text { production }\end{array}$ & Low revenue \\
\hline $\begin{array}{l}6 \text { Shifting commodity, from } \\
K \text {. alvarezi to } E \text {. } \\
\text { spinossum. }\end{array}$ & High production, faster cycle & $\begin{array}{l}\text { Low price, } 5 \text { times } \\
\text { lower }\end{array}$ \\
\hline \multicolumn{3}{|l|}{ Economic Aspect } \\
\hline 1 Far from market access & $\begin{array}{l}\text { High cost in transporting seaweed } \\
\text { yield } \\
\text { Low price offer }\end{array}$ & $\begin{array}{l}\text { Dependent on the } \\
\text { middlemen and have } \\
\text { no price control }\end{array}$ \\
\hline $\begin{array}{l}2 \text { Monopolistic market, } \\
\text { with a single middle man }\end{array}$ & Low price offer & Lowering production \\
\hline $\begin{array}{l}3 \text { Improper financial } \\
\text { planning of seaweed } \\
\text { production }\end{array}$ & Cost inefficiency, miss management & Lowering production \\
\hline $\begin{array}{l}4 \text { The rise of production } \\
\text { cost due to the technical } \\
\text { aspect occurs }\end{array}$ & Economic loss & Quit farming \\
\hline
\end{tabular}

Revitalization in business seaweed farming is a major issue for local and state governments. Some assistance and funds have been delivered to the impacted group of the ruined business. In Milangodaa, Popayato Timur, the government built a dock and built a seaweed warehouse $1269 \mathrm{~m}^{2}$ wide. It also has several types of equipment such as seaweed 
lines and wide plastic sheets for drying the seaweed. However, the disintegration among stakeholders often happened during this revitalization process. Our finding in listing the unintentional effect of seaweed farming revitalization consists of internal and external factors that main of the problem is caused by the unequal access to the facilities given. Hereby the listed factors that causing slow progress of revitalization.

Table 3. Price and the profit comparison between K. alvarezii 2015, 2019 and E. spinossum 2019 (USD).

\begin{tabular}{lrrr}
\hline \multicolumn{1}{c}{ Criteria } & $\begin{array}{c}\text { K. alvarezii 2015 } \\
\text { (USD) }\end{array}$ & $\begin{array}{c}\text { K. alvarezii 2019 } \\
\text { (USD) }\end{array}$ & $\begin{array}{c}\text { E. spinossum } \\
\text { 2019 (USD) }\end{array}$ \\
\hline Price (per kg) & 1.28 & 0.94 & 0.21 \\
Gross revenue (/2 months) & 321.15 & 160.58 & 53.53 \\
Cost (per 2 months) & 13.70 & 13.70 & 13.70 \\
Net (per month) & 153.73 & 73.44 & 19.91 \\
\hline
\end{tabular}

Table 4. The unintentional cause of the seaweed revitalization program.

\begin{tabular}{ll}
\hline \multicolumn{1}{c}{ External Factors } & \multicolumn{1}{c}{ Internal Factors } \\
\hline - Unequal spread information to all the & - Less motivation to cultivate seaweed due to \\
seaweed farmers. & the low price of dried seaweed. \\
- Overlap management from the state, regency & - Unequal access to the fund and facilities \\
and village government. & \\
& $\begin{array}{l}\text { - Polarization of the group makes friction } \\
\text { among farmers. }\end{array}$ \\
\hline
\end{tabular}

\section{Discussion}

Farmers faced a circumstance where production is not feasible. The effort surpasses the revenue. This way made farmers unwilling to do seaweed farming. The low price of $E$. spinossum made not only farmers but the entire seaweed supply chain reform their market channel. Bigger buyers seek to continue supply from seaweed farming areas because without its presence the business will be at risk. They tend to seek the closest seaweed production area where distribution cost is low, maintenance and monitoring are easy and certainty seaweed potential. Those considerations resulted in a sufficient margin to run the business. On the other hand, seaweed farmers have limited seaweed plots, small boats, and degenerating environmental conditions. That business system is ineffective and inefficient. The production efficiency can be done with the expansion of seaweed farming plot runs by an individual that will increase their harvest, and lure the buyer to come. Collective harvest from every individual in Milangodaa, Popayato Timur is possible to be done. The warehouse to keep the dry seaweed commodity in good quality. To maintain the given facilities optimally, and to prevent the social conflict due to the polarization that had occurred, community capacity development needs to be done in order to establish not only a farmer group but also a strong seaweed institution, consist not only the producer but also maintain the distribution and seaweed market. The potential conflict due to the polarization of exclusive access to the given facilities caused by the government could be reduced. How to reduce it is interactive communication between fisheries agency in Residence and Province with the village head and its officer. By doing this, the disintegration and miscommunication of the authoritative layers in seaweed cultivation can be avoided. The communication regarding the development plan should be in line with the village plan and the village executive will expand the information and minimize the disintegration among farmers.

Raising the capacity of the farmers in plantation and financial planning should be alongside with building the cohesion among the farmers. This should enrich the social capital 
and an inclusive business system will strengthen the supply chain system. The seaweed farmers community should own big storage capacity for seaweed to keep their harvest in good quality. The scheduled plantation will make seaweed supply continue. This continuity is a basis for harvest strategy so that the minimum income can be reached by the farmers. The technical approach with increasing the area of cultivation, do the harvest strategy, strengthening the paved road facilities and dock also boat capacity is suggested to be done. This will help to reduce costs and increase revenue. The attractive revenue made seaweed guarantee the continuity of seaweed supply. Continuity of supply is hoped could lure a lot of buyers so the marketing channels will be varied.

We would like to thank the Faculty of Agriculture, Gadjah Mada University for supporting this research. We also thank the Village Head of Milangodaa Village, Popayato Timur and its officer for the field assistant.

\section{References}

1. R. S. Simbahon, M. A. Ricohermoso. Developments in seaweed farming in Southeast Asia. In L. M. B. Garcia (Ed.), Responsible Aquaculture Development in Southeast Asia. Proceedings of the Seminar-Workshop on Aquaculture Development in Southeast Asia organized by the SEAFDEC Aquaculture Department, 12-14 October 1999, Iloilo City, Philippines (pp. 99-102). Tigbauan, Iloilo, Philippines: SEAFDEC Aquaculture Department. (2001).

2. FAO. The global status of seaweed production, trade and utilization. GLOBEFISH RESEARCH PROGRAMME 124. Rome. 120 pp. License: CC BY-N-SA 3.0 IGO. (2018)

3. J. K. Kim, C. Yarish, E. K. Hwang, M. Park, and Y. Kim. Seaweed aquaculture: cultivation technologies, challenges and its ecosystem services. Algae 2017, 32(1): 113. https://doi.org/10.4490/algae.2017.32.3.3. (2017)

4. D. R. D. Eranza, A. Bahron, J. Alin. Sustaining Seaweed Farming in Malaysia. The International Journal Of Business \& Management (ISSN 2321 -8916), 3(3) (2015).

5. O. Wendy, Ed. M. Holborn, Ormskirk. Developments in Sociology; Triangulation in Social Research: Qualitative and Quantitative Can Really be Mixed. Causeway Press. (2004)

6. M. M. Donna, S. Hase-Biber. Triangulation and Mixed Method Research; Provocative position. Journal of Mixed Methods researcg. 6(2) 75-79. Doi: 10.1177/1558689812437100 (2012)

7. World Bank Group. Environment and Natural Resources. Seaweed Aquaculture for Food Security, Income Generation and Environmental Health in Tropical Developing Countries. Public Disclosure Authorized. Pp 1-16.

8. Seaweed trade Indonesia-Global. https//:www.resourcetrade.earth./data (2019)

9. Badan Standar Nasional. SNI 7579.2: 2010. 